ANL-04/38

\title{
BIOLOGICAL ASSESSMENT OF THE EFFECTS OF CONSTRUCTION AND OPERATION OF A DEPLETED URANIUM HEXAFLUORIDE CONVERSION FACILITY AT THE PORTSMOUTH, OHIO, SITE
}

\author{
Environmental Assessment Division \\ Argonne National Laboratory \\ Argonne, Illinois
}

\author{
Prepared for \\ U.S. Department of Energy \\ Oak Ridge Operations Office \\ Oak Ridge, Tennessee
}

February 2004 



\section{CONTENTS}

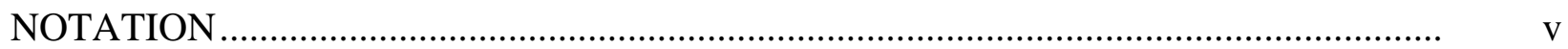

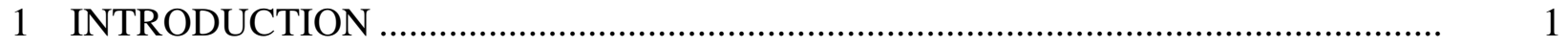

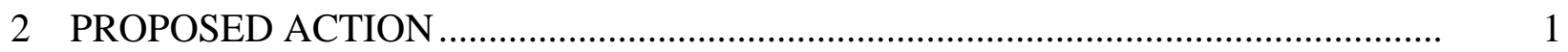

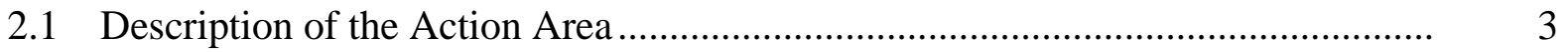

2.2 Listed Species in the Action Area...................................................................... 7

2.3 Effects of the Proposed Action on Listed Species and Designated Critical Habitat ...................................................................... 9

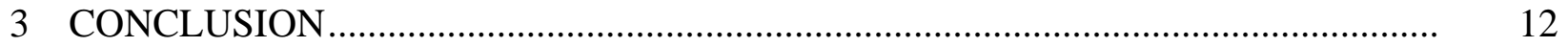

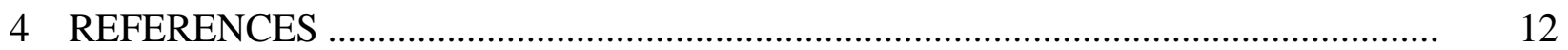

\section{FIGURES}

1 Regional Map of the Portsmouth Site Vicinity ........................................................ 2

2 Conversion Facility Candidate Locations and Proposed Cylinder Yards at the Portsmouth Site.

3 Proposed Facility Design at Location A ................................................................. 5 


\section{NOTATION}

The following is a list of the acronyms, initialisms, and abbreviations (including units of measure) used in this document.

\section{ACRONYMS, INITIALISMS, AND ABBREVIATIONS}

$\begin{array}{ll}\text { ANL } & \text { Argonne National Laboratory } \\ \text { BA } & \text { biological assessment } \\ \text { BCI } & \text { Bat Conservation International } \\ \text { DOE } & \text { U.S. Department of Energy } \\ \text { DUF }_{6} & \text { depleted uranium hexafluoride } \\ \text { ETTP } & \text { East Tennessee Technology Park } \\ \text { GDP } & \text { gaseous diffusion plant } \\ \text { HF } & \text { hydrofluoric acid } \\ \text { LMES } & \text { Lockheed Martin Energy Systems, Inc. } \\ \text { USFWS } & \text { U.S. Fish and Wildlife Service }\end{array}$

\section{UNITS OF MEASURE}

$\begin{array}{ll}{ }^{\circ} \mathrm{C} & \text { degree(s) Celsius } \\ \mathrm{cm} & \text { centimeter(s) } \\ \mathrm{d} & \text { day(s) } \\ { }^{\circ} \mathrm{F} & \text { degree(s) Fahrenheit } \\ \mathrm{ft} & \text { foot(feet) } \\ \mathrm{ft}^{2} & \text { square foot(feet) } \\ \mathrm{ha} & \text { hectare(s) } \\ \mathrm{in} . & \text { inch(es } \\ \mathrm{km} & \text { kilometer(s) } \\ \mathrm{m} & \text { meter(s) } \\ \mathrm{m}^{2} & \text { square meter(s) } \\ \mathrm{m}^{3} & \text { cubic meter(s) } \\ \mu \mathrm{gg} & \text { microgram(s) } \\ \mathrm{mi} & \text { mile(s) } \\ \mathrm{mrem} & \text { millirem(s) } \\ \mathrm{oz} . & \text { ounce(s) } \\ \mathrm{t} & \text { metric ton(s) } \\ \mathrm{yr} & \text { year(s) }\end{array}$




\section{BIOLOGICAL ASSESSMENT OF THE EFFECTS OF CONSTRUCTION AND OPERATION OF A DEPLETED URANIUM HEXAFLUORIDE CONVERSION FACILITY AT THE PORTSMOUTH, OHIO, SITE}

\section{INTRODUCTION}

The U.S. Department of Energy (DOE) Depleted Uranium Hexafluoride (DUF6) Management Program evaluated alternatives for managing its inventory of $\mathrm{DUF}_{6}$ and issued the Programmatic Environmental Impact Statement for Alternative Strategies for the Long-Term Management and Use of Depleted Uranium Hexafluoride (DUF6 PEIS) in April 1999 (DOE 1999). The $\mathrm{DUF}_{6}$ inventory is stored in cylinders at three DOE sites: Paducah, Kentucky; Portsmouth, Ohio; and East Tennessee Technology Park (ETTP), near Oak Ridge, Tennessee. In the Record of Decision for the DUF $_{6}$ PEIS, DOE stated its decision to promptly convert the DUF $_{6}$ inventory to a more stable chemical form. Subsequently, the U.S. Congress passed, and the President signed, the 2002 Supplemental Appropriations Act for Further Recovery from and Response to Terrorist Attacks on the United States (Public Law No. 107-206). This law stipulated in part that, within 30 days of enactment, DOE must award a contract for the design, construction, and operation of a DUF 6 conversion plant at the Department's Paducah, Kentucky, and Portsmouth, Ohio, sites, and for the shipment of DUF $_{6}$ cylinders stored at ETTP to the Portsmouth site for conversion. This biological assessment (BA) has been prepared by DOE, pursuant to the National Environmental Policy Act of 1969 and the Endangered Species Act of 1974, to evaluate potential impacts to federally listed species from the construction and operation of a conversion facility at the DOE Portsmouth site.

\section{PROPOSED ACTION}

DOE proposes to construct and operate a conversion facility at the Portsmouth site for conversion of the DUF $_{6}$ inventory stored at the Portsmouth and ETTP sites. Figure 1 shows the Portsmouth site and vicinity. The proposed action includes shipment of the ETTP cylinders to Portsmouth and construction of a new cylinder storage yard at Portsmouth for the ETTP cylinders, if required.

The proposed action also includes the preparation of cylinders for shipment from ETTP. Cylinders that are not in compliance with Department of Transportation (DOT) requirements would be placed into protective overpacks. No construction activities would be required, and no disturbance to areas outside the ETTP cylinder storage yards would be expected. The only equipment required would be similar to the equipment currently used during routine cylinder handling and maintenance activities. The cylinder transfer option would involve the transfer of the DUF $_{6}$ from noncompliant cylinders to cylinders that meet all DOT requirements. If selected, this option would likely require the construction of a cylinder transfer facility at ETTP. 


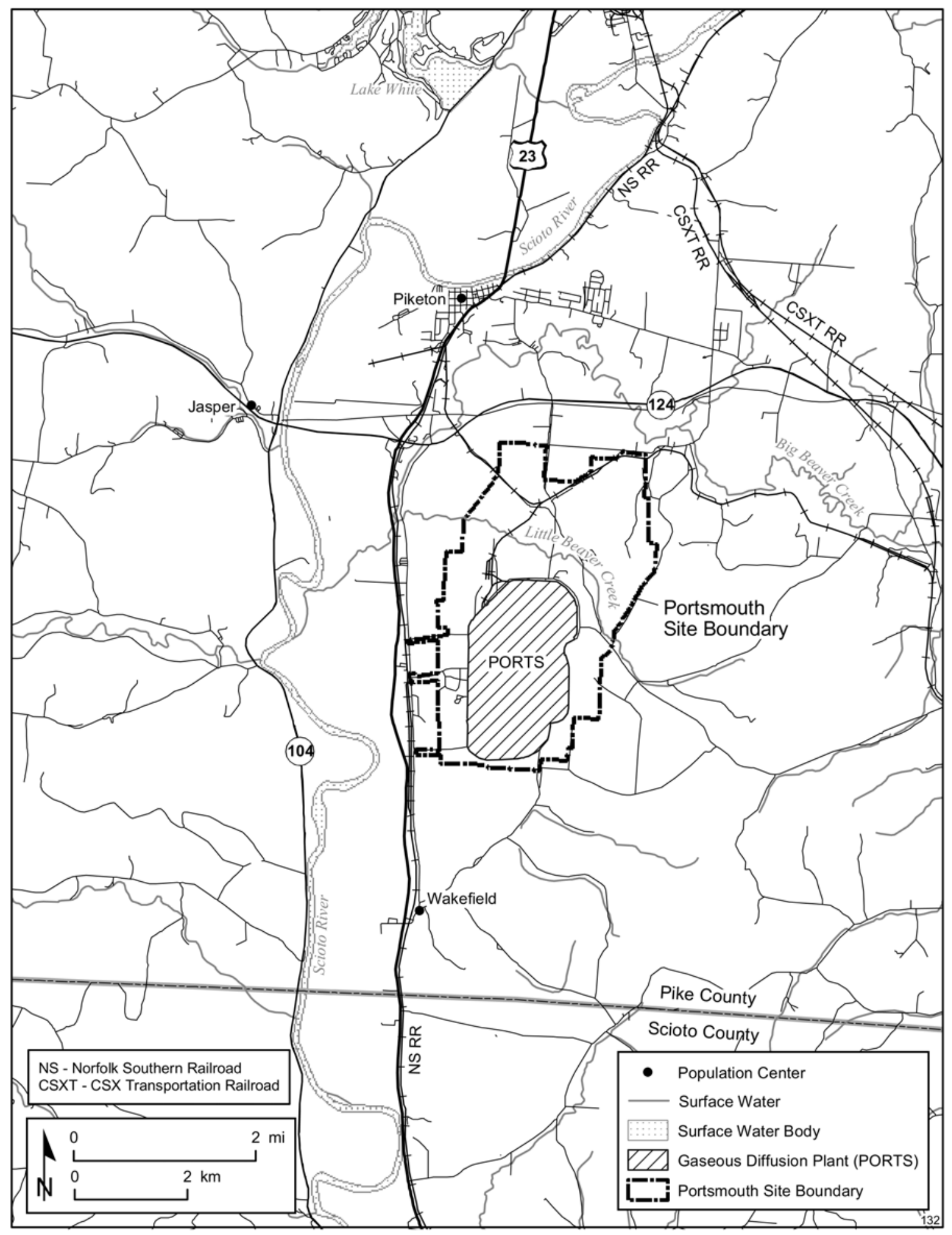

FIGURE 1 Regional Map of the Portsmouth Site Vicinity (Source: Adapted from Lockheed Martin Energy Systems, Inc. [LMES] 1996) 
Currently, there are no plans or proposals to build or use a cylinder transfer facility to prepare DUF $_{6}$ cylinders for shipment. If a decision is made to construct a cylinder transfer facility, a separate environmental review would be conducted.

Three noncontiguous areas comprise Proposed Area 1 for the construction of a new cylinder storage yard at the Portsmouth site, if new yard construction is required. These areas are located in the northwestern portion of the developed area of the Portsmouth site, which is bounded by Perimeter Road (Figure 2). Two noncontiguous areas comprise Proposed Area 2, an alternative area for the construction of new cylinder storage yards. These areas are also located in the northwest portion of the developed area. In addition, an existing concrete pad would be used with Proposed Area 2 for cylinder storage.

The conversion facility would convert $\mathrm{DUF}_{6}$ into a stable chemical form, uranium oxide $\left(\mathrm{U}_{3} \mathrm{O}_{8}\right)$, for beneficial use or disposal. The off-gas from the conversion process would yield hydrofluoric acid (HF), which would be processed and marketed or converted to a solid for sale or disposal. To support the conversion operations, the emptied DUF6 cylinders would be stored, handled, and processed for disposal. The time period considered is a construction period of approximately 2 years, an operational period of 18 years, and the decontamination and decommissioning of the facility. Current plans call for the construction to begin in the summer of 2004.

The Portsmouth plant is being designed to convert 14,900 tons (13,500 metric tons) of DUF $_{6}$ per year, requiring 18 years to convert the Portsmouth and ETTP inventories. The conversion facility would occupy a total of approximately 10 acres (4 ha), with up to 65 acres (26 ha) of land disturbed. Some of the disturbed areas would be areas cleared for railroad or utility access, not adjacent to the construction area.

This BA evaluates the construction and operation of the conversion facility at one primary location within the Portsmouth site and two alternative locations. The three candidate locations, denoted as Locations A, B, and C, are shown in Figure 2. Location A is the preferred location for the conversion facility (Figure 3), and this BA evaluates facility construction and operation at Location A as the base case analysis. Locations B and C are evaluated as alternative locations for the conversion facility within the Portsmouth site.

\subsection{DESCRIPTION OF THE ACTION AREA}

The Portsmouth site is located in Pike County, Ohio, approximately $22 \mathrm{mi}$ (35 km) north of the Ohio River and $3 \mathrm{mi}(5 \mathrm{~km})$ southeast of the town of Piketon. The Portsmouth site includes the Portsmouth Gaseous Diffusion Plant (GDP), previously operated first by DOE and then by the U.S. Enrichment Corporation. Uranium enrichment operations at the Portsmouth site were discontinued in May 2001, and the plant has been placed in cold standby, a nonoperational condition in which the plant retains the ability to resume operations within 18 to 24 months (DOE 2001). 


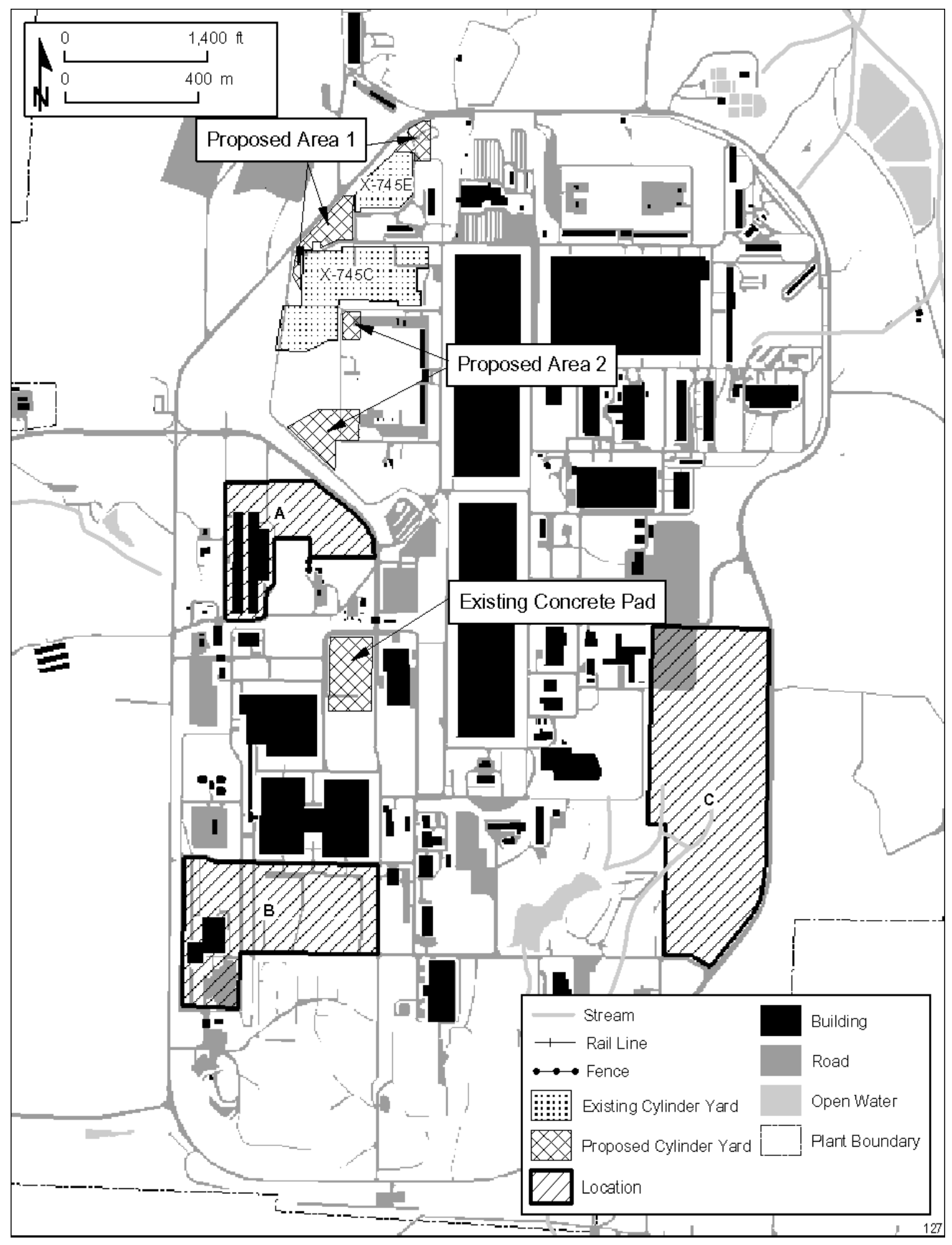

FIGURE 2 Conversion Facility Candidate Locations and Proposed Cylinder Yards at the Portsmouth Site (Source: Adapted from DOE 1996; MMES 1992a) 


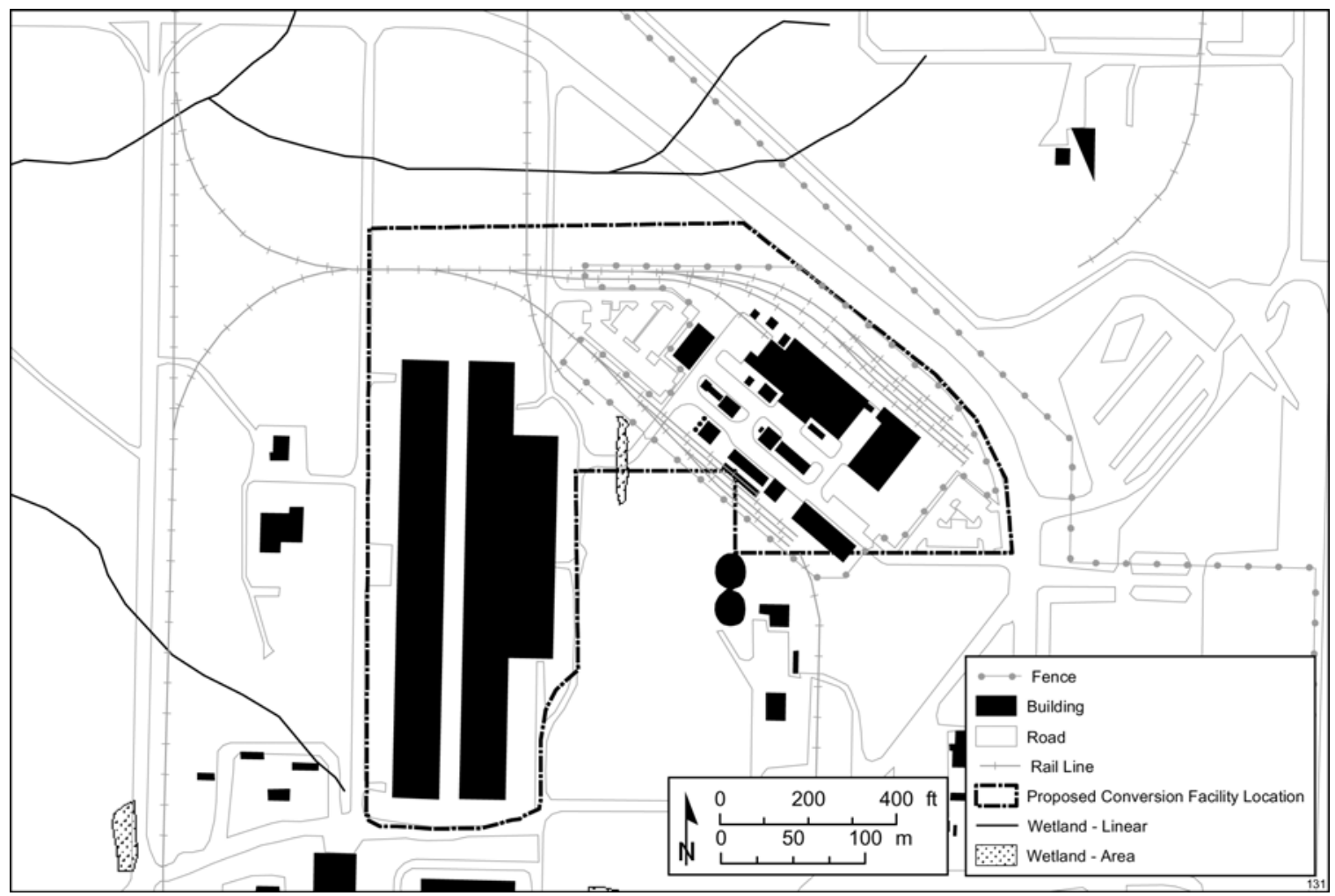

FIGURE 3 Proposed Facility Design at Location A

The Portsmouth site occupies 3,714 acres (1,500 ha) of land, with an 800-acre (320-ha) fenced core area that contains the former production facilities. The 2,914 acres (1,180 ha) outside the core area includes restricted buffers, waste management areas, plant management and administrative facilities, gaseous diffusion plan support facilities, and vacant land (Martin Marietta Energy Systems, Inc. [(MMES] 1992b). Wayne National Forest borders the plant site on the east and southeast, and Brush Creek State Forest is located slightly more than $1 \mathrm{mi}$ $(1.6 \mathrm{~km})$ southwest of the site boundary.

The DOE-managed cylinders containing $\mathrm{DUF}_{6}$ at the Portsmouth site are stored in two cylinder yards. These storage yards have concrete bases. The cylinders are stacked two high to comply with Defense Nuclear Facilities Safety Board requirements. All 10- and 14-ton (9- and 12-t) cylinders stored in these yards have been or are being inspected and repositioned. They have been placed on new concrete saddles with sufficient room between cylinders and cylinder rows to permit adequate visual inspection of the cylinders.

The most common type of vegetation on the Portsmouth site is managed grassland, which makes up 30\% of the site (about 1,100 acres [445 ha]) (DOE 2001). Grasses are the dominant species in these communities, and they are maintained by periodic mowing. Oak-hickory forest (covering 17\% of the site) occurs on well-drained upland areas, and old-field communities (11\%) occur in disturbed areas. Upland mixed hardwood forest also covers $11 \%$ of the site (400 acres [162 ha]). Black walnut, black locust, honey locust, black cherry, and persimmon are the 
dominant species in these mesic to dry upland communities. Riparian forest occurs in low, periodically flooded areas near streams and makes up 4\% of the site (153 acres [62 ha]). The dominant species in riparian forest communities are cottonwood, sycamore, willows, silver maple, and black walnut. Within the area bounded by Perimeter Road, the Portsmouth site consists primarily of open grassland (including areas maintained as lawns) and developed areas consisting of buildings, paved areas, and storage yards.

Location A is approximately 26 acres (11 ha) in size and includes previously disturbed as well as undisturbed areas. Except for the northern portion, Location A is relatively level and has been graded. Three buildings are currently located in the western portion of Location A. The northeastern portion of Location A and the area directly north of the two western-most buildings support an old-field habitat composed primarily of grasses such as fescue and broom-sedge, with crown vetch, wild carrot, and small scattered trees and shrubs. A drainage ditch bordering an old railroad bed in the east area supports sapling sycamore and black locust trees as well as mature black locust. Vegetation near the buildings is a managed grassland community and includes fescue, ox-eye daisy, and hop clover. Bulrush occurs in shallow drainage ditches. The area immediately adjacent to the buildings is frequently mowed. At the northern boundary of Location $\mathrm{A}$, the land surface slopes down to a small intermittent stream that runs near the northern margin of the location, approximately $100 \mathrm{ft}(30 \mathrm{~m})$ from the location boundary. This stream is bordered by a riparian woodland community of willow, mature sycamore, black locust, and maple. This woodland community is classified as riparian forest; however, the tree canopy is fairly open and narrow, less than $100 \mathrm{ft}(30 \mathrm{~m})$ in width. The downstream portion of this riparian area, west of Location A, supports scattered trees. Small woodland areas lie northeast and northwest of the two western-most buildings; they are continuous with the riparian woodland community bordering the stream to the north. These wooded areas are composed primarily of mature black locust trees, along with honeysuckle, sumac, and sweet clover.

Location B is approximately 50 acres (20 ha) in size. It has been disturbed by grading and construction activities and has a level ground surface. The vegetation at this location is composed entirely of a managed grassland community and generally remains unmowed. The dominant species are fescue, broom-sedge, hop clover, and birdfoot trefoil.

Location C is approximately 78 acres (32 ha) in size and has been disturbed by grading activities. This location is relatively level to gently sloping throughout and supports an open, managed grassland vegetation community that generally remains unmowed. The dominant species is fescue, with yarrow and ox-eye daisy. Two intermittent drainages in the southwestern portion of this location are bordered by narrow deciduous woodland communities (approximately $60 \mathrm{ft}$ [18 m] in width) with open tree canopies. These woodland communities are classified as upland mixed hardwood forest communities.

Proposed Area 1 for the construction of a new cylinder storage yard consists of three noncontiguous areas. The vegetation of these areas consists of previously disturbed managed grassland. Proposed Area 2 consists of two noncontiguous areas for new yard construction that also support previously disturbed managed grassland. In addition, two small drainages are located within Proposed Area 2 and drain to the southwest. These drainages combine to form the intermittent stream north of Location A. 
ETTP is located in eastern Roane County about $25 \mathrm{mi}(40 \mathrm{~km})$ west of Knoxville, Tennessee. ETTP is part of the Oak Ridge Reservation in the city of Oak Ridge, Tennessee. Uranium enrichment was the site's mission until the mid-1980s, when gaseous diffusion operations ceased. About $65 \%$ of the land within a 5-mi $(8-\mathrm{km})$ radius of the ETTP site supports oak-hickory and mixed forest, although most of the ETTP site consists of mowed grasses. There are 4,817 DUF$_{6}$ storage cylinders located in three cylinder yards at the ETTP site. All activities related to cylinder preparation would take place at the cylinder storage yards.

\subsection{LISTED SPECIES IN THE ACTION AREA}

The U.S. Fish and Wildlife Service (USFWS) provided information regarding federally listed endangered or threatened species that may occur in the vicinity of the Portsmouth site (Knapp 2002). The USFWS indicated that the site lies within the range of the Indiana bat (Myotis sodalis), federally listed as endangered, and the timber rattlesnake (Crotalus horridus). Although the latter species has not been assigned a federal listing status, the USFWS has initiated a prelisting Conservation Action Plan to support state and local conservation efforts (Knapp 2002).

The Indiana bat was federally listed as an endangered species on March 11, 1967 (USFWS 1967). Critical habitat, consisting of 11 caves and 2 mines in 6 states that are used as winter hibernacula, was designated in 1976. The USFWS published a recovery plan for the Indiana bat in 1983, and a draft revised recovery plan in 1999 (USFWS 1999). The current range of the Indiana bat includes 23 states, covering most of the eastern half of the United States. The total population size, based on 1995 to 1997 surveys, is estimated at about 353,000. The largest winter hibernation populations occur in Indiana, Kentucky, and Missouri, comprising more than 85\% of the total population. Half of all hibernating Indiana bats occur in Indiana (USFWS 1999).

The Indiana bat is a small to medium-sized bat, approximately 1.6 to 1.9 in. (41 to $49 \mathrm{~mm}$ ) in length, and 0.2 to $0.4 \mathrm{oz}$. (5 to $11 \mathrm{~g}$ ) in weight (USFWS 1999; BCI 2001). The fur is a dull grayish chestnut brown on the back and somewhat lighter on the chest and belly. The Indiana bat is a migratory species, overwintering in hibernacula and dispersing to summer roosting areas in spring.

Hibernacula consist mostly of large caves, but also include abandoned mines, and they are principally located in areas of limestone karst. Relatively few sites provide the conditions required by Indiana bats for hibernation; thus suitable hibernacula often support large numbers of Indiana bats. Suitable sites maintain a stable low temperature during winter, ideally between $37^{\circ}$ and $43^{\circ} \mathrm{F}\left(3^{\circ}\right.$ and $6^{\circ} \mathrm{C}$ ). Indiana bats emerge from hibernation in late March and April and migrate to summer roosting areas, where they arrive in mid-April or May (BCI 2001). In August, Indiana bats slowly begin the return migration to hibernacula, which may be $300 \mathrm{mi}(500 \mathrm{~km})$ or more from summer roosting areas, and enter hibernation in late September and October. Individual bats generally return to the same hibernaculum each year (USFWS 1999; BCI 2001).

During summer, males generally roost singly or in small groups throughout the range of the species. Females form maternity colonies of about 25 to 50 individuals, but may include as many as 100 individuals. Female Indiana bats return to the same summer roosting areas each 
year. Collection data suggest that many female Indiana bats may migrate north in the spring. Woodlands in the glaciated Midwest may have a higher density of maternity colonies compared with the other portions of the species' range, although further studies are needed to confirm this (USFWS 1999).

Indiana bats typically roost beneath the bark of large dead or dying trees with loose exfoliating bark, or live trees with loose bark, such as shagbark hickory. Cavities and crevices in trees may also be used. A variety of roost trees are needed within the traditional summer range of a maternity colony. A maternity site generally contains one or more primary roost trees (used by a majority of the bats throughout the summer), with a number of alternate roost trees (used intermittently and by fewer bats) generally located nearby. Optimal maternity roost trees are over 16 in. $(40 \mathrm{~cm})$ in diameter at breast height. Individual bats within the maternity colony move among roost trees during a season, and from year to year if a roost tree becomes unavailable. Roost trees may be lost or become unsuitable, for example, because of loss of bark. Most roost trees may be usable for only 2 to 8 years (USFWS 2002).

Roost trees are generally located in riparian forest, bottomland floodplain forest, and upland forest. Primary roosts are typically located at forest edges and in openings, or in forested areas with open canopies and open understories, and receive direct solar exposure (USFWS 1999). Alternate roosts may be located in forest interiors or in the open. Roost trees may be occupied by maternity colonies from mid-April to mid-September (USFWS 2002).

Indiana bats forage between dusk and dawn on flying insects. They forage in and around the tree canopy, and use a variety of habitats for foraging, primarily riparian forest and floodplain forest (such as forested stream corridors and impounded water bodies), but also use upland forest, forest edges, old fields, and pastures with scattered trees. Foraging areas used by pregnant and lactating females are generally within $1.5 \mathrm{mi}(2.5 \mathrm{~km})$ of their roost (USFWS 1999).

Indiana bat population declines have primarily been associated with disturbances to hibernacula. Human disturbances causing bat mortality have included arousal during hibernation, which reduces limited fat reserves and vandalism. The construction of gates at cave entrances, thereby excluding bats or causing disruptions in cave air flow that result in temperature changes, has also resulted in population declines. In addition, flooding of hibernacula, ceiling collapse, or unusually cold winter temperatures have resulted in losses of Indiana bats. Population declines may also possibly result from the loss or degradation of summer roosting or foraging habitat, or exposure to pesticides, through consumption of prey or foraging in recently sprayed areas, although further study of these factors is needed (USFWS 1999).

The Indiana bat has been reported in the area of the Portsmouth site and may occur on the site during spring or summer. However, Indiana bats have not been observed on the site, and no Indiana bats were collected during surveys in 1994 and 1996 in areas identified as potential summer habitat (DOE 1997). Roosting and nursery sites may include forested areas with loose barked trees (such as shagbark hickory) and standing dead trees. Potential summer habitat for the Indiana bat was identified outside the developed area bounded by Perimeter Road, within the corridors along Little Beaver Creek, the Northwest Tributary stream, and a wooded area east of 
the X-100 facility (this facility is located near the northern end of Location C; see Figure 2). However, most of the Portsmouth site was found to have poor summer habitat because of the small size, isolation, and insufficient maturity of the few woodlands on the site. These woodlands would be unlikely to be used by Indiana bats because of the availability of higher quality habitat elsewhere in the vicinity. Locations $\mathrm{A}, \mathrm{B}$, and $\mathrm{C}$ do not support suitable habitat for the Indiana bat. Although Locations A and C contain small wooded areas, the small size and lack of suitable maturity of these areas indicate that they would probably provide poor habitat for Indiana bats.

The timber rattlesnake, listed by the State of Ohio as endangered, occurs in the vicinity of the Portsmouth site but has not been found on the site. Habitat for the timber rattlesnake is found on and near high, dry ridges. The timber rattlesnake winters in dens, generally consisting of narrow crevices in bedrock, often with a southeast or southwest exposure. Protection of winter dens is believed to be critical to the continued survival of the species (Knapp 2002). Habitat for the timber rattlesnake does not occur on or near any of the three candidate locations.

No construction activities would take place at the ETTP site, and no disturbance to areas outside the ETTP cylinder storage yards would be expected. No federally listed threatened or endangered species are associated with the cylinder storage yards.

\subsection{EFFECTS OF THE PROPOSED ACTION ON LISTED SPECIES AND DESIGNATED CRITICAL HABITAT}

Three noncontiguous areas comprise Proposed Area 1 for the construction of a new cylinder storage yard at the Portsmouth site. Construction of the yard would result in the disturbance of approximately 6.1 acres (2.5 ha) of land, due to construction-related activities, and in the loss of previously disturbed managed grassland vegetation. The yards would not eliminate undisturbed natural communities.

Construction of a storage yard at Proposed Area 1 would not be expected to result in direct or indirect impacts to the Indiana bat or timber rattlesnake. Although the riparian forest along the stream north of Perimeter Road may potentially include trees that can be used by Indiana bats for roosting, this area has not been identified as summer roosting habitat and is unlikely to be used by Indiana bats. Higher quality habitat is available in the vicinity. Although noise associated with construction activities may disturb wildlife, Indiana bats that may use habitats near the Portsmouth site are currently exposed to noise and other effects of human disturbance. In addition, Indiana bats have been observed to tolerate increased noise levels from human activities (a summer roosting habitat occupied by an Indiana bat maternity colony is located near Indianapolis International Airport and an interstate highway) (USFWS 2002). Consequently, construction activities would be unlikely to result in avoidance of these areas by Indiana bats.

Two noncontiguous areas comprise Proposed Area 2 for the construction of a new cylinder storage yard. Construction of the yard would result in the disturbance of approximately 6.9 acres (2.8 ha) of land, resulting from construction-related activities. Impacts to vegetation 
and wildlife would be similar to those for Proposed Area 1. Impacts to the Indiana bat or timber rattlesnake would not be expected.

Constructing a conversion facility at Location A would result in the loss of about 10 acres (4 ha) of previously disturbed managed grassland and old-field vegetation within the facility footprint. The facility would not eliminate undisturbed natural communities. Facility construction at Location A would not be expected to result in direct or indirect impacts to the Indiana bat or timber rattlesnake.

Although construction-related activities would primarily affect managed grassland and old-field vegetation, impacts to the wooded areas at Location A would also occur during the construction period. Construction of the conversion facility access road and rail lines would result in impacts to several wooded areas within Location A, resulting in the removal of trees. These areas, east, north, and northwest of the existing buildings, primarily support sapling and moderate-size mature black locust.

The total area of construction-related disturbance, however, would be approximately 65 acres (26 ha) in size, and additional impacts to wooded areas could occur unless temporary construction areas, such as lay-down areas, were positioned outside Location A in adjacent, previously disturbed areas. Trees with exfoliating bark, such as shagbark hickory or dead trees with loose bark, can be used by the Indiana bat for roosting during the summer. However, the wooded areas at Location A are not considered to be suitable summer habitat and are unlikely to be used by Indiana bats. If facility construction required the disturbance of all Location A, the entire wooded habitat at this location would potentially be eliminated. In addition, minor impacts to the riparian community along the intermittent stream may occur west of Location A, near the point of connection of the new rail line with the existing line immediately east of Perimeter Road (Figure 3). Trees are scattered along this portion of the stream channel, and removal of trees at this location may be avoidable.

If live or dead trees with exfoliating bark are encountered in construction areas, they should be saved if possible. If necessary, the trees should be cut before April 15 or after September 15. Increased noise, lighting, and human presence during the construction of the new rail line adjacent to the riparian forest habitat along the northern margin of Location A could disturb wildlife using that habitat. However, Indiana bats that may use habitat near the Portsmouth site would be currently exposed to noise and other effects of human disturbance, and Indiana bats have been observed to tolerate increased noise levels. Consequently, construction activities would be unlikely to result in avoidance of these areas by Indiana bats.

Location B does not support habitat for the Indiana bat or timber rattlesnake; therefore, construction at this location would not impact these species. Although impacts to the woodland habitats at Location $C$ could occur, these wooded areas have not been identified as Indiana bat summer habitat and are unlikely to be used by Indiana bats. In addition, impacts to the wooded areas at Location $\mathrm{C}$ could likely be avoided by facility placement in the northern portion of this location. Location $\mathrm{C}$ does not support habitat for the timber rattlesnake and, therefore, this species would not be impacted by construction at this location. In addition, because of existing human disturbance in the vicinity of Locations $\mathrm{A}, \mathrm{B}$, and $\mathrm{C}$, the construction of a conversion 
facility would not affect the quality of potential Indiana bat habitat along Little Beaver Creek, the Northwest Tributary Stream, or the wooded area east of the X-100 facility.

Impacts to the Indiana bat or timber rattlesnake during operation of a conversion facility at Location A, B, or C are not expected. Increased noise, lighting, and human presence because of facility operation at Location A and the movement of railcars along the new rail line west of the facility may disturb wildlife in the adjacent riparian forest habitat. However, Indiana bats that may be using habitat near the Portsmouth site are currently exposed to noise and other effects of human disturbance due to operation of the site, including vehicle traffic. In addition, Indiana bats have been observed to tolerate increased noise levels. Consequently, facility operations would be unlikely to result in avoidance of these areas by Indiana bats, particularly since the wooded areas at Location A have not been identified as summer roosting habitat and are unlikely to be used by Indiana bats. Impacts to the Indiana bat and timber rattlesnake from the operation of a conversion facility at Locations B or $\mathrm{C}$ would be similar to impacts at Location A. The operation of a conversion facility at Location $\mathrm{C}$ may similarly disturb wildlife in the wooded areas at that location. These habitats, however, also have not been identified as Indiana bat habitat and are unlikely to be used by Indiana bats. Because habitat for the timber rattlesnake is not present at or near any of the candidate locations, facility operation would not result in disturbance to that species.

During operations, atmospheric emissions from the facility stacks would occur; however, emissions levels would be extremely low. Facility emissions would include trace amounts of uranium. The highest average air concentration of uranium compounds would result in a radiation exposure to the general public (nearly $100 \%$ due to inhalation) of $2.07 \times 10^{-5} \mathrm{mrem} / \mathrm{yr}$, well below the DOE guideline of $100 \mathrm{mrem} / \mathrm{yr}$ (0.00027 rad/d [DOE 2002]). Wildlife species are less sensitive to radiation than humans (DOE guidelines require an absorbed dose limit to terrestrial animals of less than 40,000 mrem/yr [0.1 rad/d] [DOE 2002]). Therefore, impacts on wildlife due to radiation effects are expected to be negligible. Expected emissions are many orders of magnitude below toxic effect levels of chronic inhalation of uranium. Therefore, toxic effects on wildlife, including the Indiana bat and timber rattlesnake, as a result of inhalation of uranium compounds are also expected to be negligible.

The maximum annual average air concentration of HF that would result from operation of a conversion facility would be $0.006 \mu \mathrm{g} / \mathrm{m}^{3}$. Toxic effect levels of chronic inhalation of HF are many orders of magnitude greater than expected emissions. Therefore, toxic effects on wildlife, including the Indiana bat and timber rattlesnake, from HF emissions are expected to be negligible.

No impacts to federally listed endangered or threatened species would occur from the preparation of cylinders for shipment from ETTP. The potential on-site impacts from preparing DOT compliant cylinders and from placing noncompliant cylinders into overpacks would be small and limited to involved workers. No impacts to the environment would occur because no releases would be expected and no construction activities would be required. The only equipment required would be similar to the equipment currently used during routine cylinder handling and maintenance activities. The cylinder transfer option would involve the transfer of the $\mathrm{DUF}_{6}$ from noncompliant cylinders to cylinders that meet all DOT requirements. If selected, this option 
would likely require the construction of a cylinder transfer facility at ETTP. Currently, there are no plans or proposals to build or use a cylinder transfer facility to prepare DUF $_{6}$ cylinders for shipment.

The cumulative impacts to the Indiana bat should be negligible for any alternative considered in this BA in conjunction with the effects of other activities. Construction of a conversion facility at Location A would likely result in the removal of trees. However, impacts to potential Indiana bat habitat from other actions on the Portsmouth site are not anticipated. No impacts to the timber rattlesnake would occur under any alternative; therefore, there would be no contribution to cumulative impacts.

\section{CONCLUSION}

The Indiana bat is known to occur in the area of the Portsmouth site and may potentially occur on the site during spring or summer. Evaluations of the Portsmouth site indicated that most of the site was found to have poor summer habitat for the Indiana bat because of the small size, isolation, and insufficient maturity of the few woodlands on the site. Potential summer habitat for the Indiana bat was identified outside the developed area bounded by Perimeter Road, within the corridors along Little Beaver Creek, the Northwest Tributary stream, and a wooded area east of the X-100 facility. However, no Indiana bats were collected during surveys of these areas in 1994 and 1996. Locations A, B, and C do not support suitable habitat for the Indiana bat and would be unlikely to be used by Indiana bats. Indiana bat habitat also does not occur at Proposed Areas 1 and 2. Although Locations A and C contain small wooded areas, the small size and lack of suitable maturity of these areas indicate that they would provide poor habitat for Indiana bats. Trees that may be removed during construction would not be expected to be used for summer roosting by Indiana bats. Disturbance of Indiana bats potentially roosting or foraging in the vicinity of the facility during operations would be very unlikely, and any disturbance would be expected to be negligible. On the basis of these considerations, DOE concludes that the proposed action is not likely to adversely affect the Indiana bat. No critical habitat exists for this species in the action area.

Although the timber rattlesnake occurs in the vicinity of the Portsmouth site, it has not been observed on the site. In addition, habitat for the timber rattlesnake is not present on the Portsmouth site. Therefore, DOE concludes that the proposed action would not affect the timber rattlesnake.

\section{REFERENCES}

Bat Conservation International (BCI), 2001, Bats in Eastern Woodlands, produced by Bat Conservation International, Austin, Texas, for U.S. Forest Service Regions 8 and 9 and U.S. Fish and Wildlife Service. Available at http://www.batcon.org/nabcp/newsite/forrep.pdf. Accessed July 28, 2003. 
DOE (U.S. Department of Energy), 1996, Technical Report on Affected Environment for the DOE Sites Considered in the DOE Waste Management Programmatic Environmental Impact Statement (WM PEIS), Vols. I and II, META/Berger-SR-01, prepared by META/Berger, Gaithersburg, Md., for DOE, Office of Environmental Management, Dec.

DOE, 1997, Final Threatened and Endangered Species Report, DOE/OR/11-1668\&DO, POEF-LMES-166, prepared by Environmental Compliance Division, Lockheed Martin Energy Systems, Inc., Oct.

DOE, 2001, Environmental Assessment: Winterization Activities in Preparation for Cold Standby at the Portsmouth Gaseous Diffusion Plant, Piketon, Ohio, DOE/EA-1392, Oak Ridge Operations Office, Oak Ridge, Tenn., June.

DOE, 2002, A Graded Approach for Evaluating Radiation Doses to Aquatic and Terrestrial Biota, DOE-STD-1153-2002, Washington, D.C., July.

Knapp, M., 2002, personal communication from Knapp, Field Supervisor, U.S. Fish and Wildlife Service to J. Elmore (Oak Ridge Operations Office, U.S. Department of Energy), Oak Ridge, Tenn., Sept. 23.

LMES (Lockheed Martin Energy Systems, Inc.), 1996, Portsmouth Site Annual Environmental Report for 1994, ES/ESH-63 (POEF-3055), prepared by Environmental, Safety, and Health Compliance and Environmental Management staffs, Oak Ridge, Tenn., and Environmental Management Division, Portsmouth Site, Piketon, Ohio, for U.S. Department of Energy, March.

MMES (Martin Marietta Energy Systems, Inc.), 1992a, Site Development Plan, Portsmouth Uranium Enrichment Plant, POEF-3001, prepared by MMES, Site and Facilities Planning Department, Piketon, Ohio, for U.S. Department of Energy, July 31.

MMES, 1992b, Technical Site Information, Portsmouth Uranium Enrichment Plant, POEF-2059, prepared by MMES, Site and Facilities Planning, Piketon, Ohio, for U.S. Department of Energy, July.

USFWS (U.S. Fish and Wildlife Service), 1967, "Endangered Species List,” Federal Register 32:4001.

USFWS, 1999. Agency Draft Indiana Bat (Myotis sodalis) Revised Recovery Plan. Fort Snelling, Minnesota.

USFWS, 2002, Biological Opinion on the Application for an Incidental Take Permit for the Federally Endangered Indiana Bat (Myotis sodalis) for the Six Points Road Interchange and Associated Development, Hendricks and Marion Counties, Indiana, prepared by U.S. Fish and Wildlife Service, Bloomington Field Office, Bloomington, Ind. 
